\title{
Providing Young Families With Housing in Russia: Financial, Economical, Administrative, and Regulatory Aspects
}

\author{
Ekaterina Alexandrovna Eremeeva ${ }^{1}$, Natalia Vasilievna Volkova ${ }^{1}$ \& Tatiana Viktorovna Khalilova ${ }^{1}$ \\ ${ }^{1}$ Department of State and Municipal Administration, Institute of Management, Economics and Finance, Kazan \\ Federal University, Kazan, Russia \\ Correspondence: E.A. Eremeeva, Department of State and Municipal Administration, Institute of Management, \\ Economics and Finance, Kazan Federal University, Kazan, Russia. E-mail: anka_2007_901@mail.ru
}

Received: September 2, 2020

Accepted: October 20, 2020

Online Published: December 24, 2020

doi:10.5430/ijfr.v12n1p123

URL: https://doi.org/10.5430/ijfr.v12n1p123

\begin{abstract}
This article considers methods of state support of young families in Russia and Russian regions. In current socio-economic conditions, young families' support can be viewed as a useful course of state policy. Providing housing to young families allows young adults not only to solve their social, economic, and psychological issues but also creates a background for young families for active participation in societal, economic development, and demographic state policy. Logics of the research is based on that young family support is executed in Russia on federal and regional management levels as part of youth and housing policy. In the article, regulatory, administrative, and financial aspects have been reviewed as in the frame of youth and housing policies. During their studies, methods were used, such as comparison study, compilatory analysis of documents, software, and analysis and evaluation of financial and statistical data based on algebraic calculations. Judging on the results of the study conclusion was carried out on how well young families support is organised on federal and regional levels, how effective were the measures taken for society. In conclusion, suggestions were made on how to better young families' support when acquiring housing. Their usage will allow to structure of young families' aid, make it more expedient and of current interest.
\end{abstract}

Keywords: young family, youth (young adults), housing, state support, region, Russia

\section{Introduction}

Under the current socio-economic conditions, young families' support is regarded as the primary Russian state policy. Generally, it is regarding young families' support concerning childbirth. It is due to the trend of Russian demographic policy. Nevertheless, no less significant to consider different means that build an environment for birth and raising a child. In correlation to that, fundamental status takes up measures for young families' housing provision. The importance of this young family's support direction essentially develops if the fact is taken into consideration that young families regularly experience financial troubles associated with the lack of savings, their property, high salary, or decent career. In cementing of that young families support in the salvation of the housing problem, on the one hand, targets young families and their issues salvation, and on the other hand, - positively affects social development, this course of state policy can be taken sufficient and exciting for research in this article.

The relevance of the study of this issue is confirmed by the interest in this topic in the scientific community.

The importance of comfortable and decent conditions for youth and young families is viewed differently from various opinions: as the possibility of poverty and homelessness salvation (Kennelly \& Watt, 2012); (Coulter et al., 2020 \& Parker \& Mayock, 2019) as the possibility of overcoming socio-economic conflicts of youth with parents (Palma \& Scott, 2020 \& Hikichi et al., 2020), as one of the tools of youth psychological growth (Darra et al., 2020 \& Natalier, \& Johnson, 2012), as the option of achieving a particular status in society (Galster \& Wessel, 2019; Fiori et al., 2020), etc. That means that role of housing in youth life and young families are valued from different points of view. This also tells about the necessity of state support for young families when acquiring housing.

\section{Methods}

The research includes a few steps. Logics of the research are represented by the decision that the housing issue salvation for young families appears to be multisectoral act. It is being solved on both federal and regional levels of 
state management. Besides that, it is included in youth and housing policy. With relation to that, in the framework of this deed an attempt has been made to describe implementation of this support on federal and regional levels of Russia. As an example of the analysis of regional practice, Tatarstan Republic (TR) has been chosen.

In the first phase of the research, a compilatory analysis of federal and regional regulatory acts regarding youth and young families' support has been done. On the base of acquired data, a comparison analysis of document contents was performed. First were the collate terms "young family" and demands for acknowledging it and providing support.

In the second phase, software data document analysis was performed. By the end of it, information regarding state organisations responsible for young families' support was collected and systemised. Based on this information, comparative analysis of the management system of this course directed toward supporting young families on federal and regional levels was done.

In the third phase by the results of software data document analysis and implementation measures report of young families support were generalised data regarding funding and results of young families' support in Tatarstan. Years from 2017 up to 2019 were analysed. For more detailed and enveloping research were used planned and factual indicators. The formula determines their ratio:

$$
I_{n}=\frac{A \mathrm{I}_{n}}{P \mathrm{I}_{n}} * 100 \%
$$

Where AIn - factual indication meaning, PIn - planned indication meaning, In - plan being done indicator.

As young families support acts are implemented on several management levels they receive funding from different sources. Relative ratio funds from different sources in general flow and size of subsidizing young families support were analysed in the deed. The following calculation method was used:

$$
P_{n}=\frac{S F_{n}}{T F} * 100 \%
$$

Where SFn - size of funds from a separate source, TF - total funding amount, Pn - portion of funds from that source in the total amount for providing young families with housing.

Staged usage of the methods allowed making conclusions regarding young families' support in Russia, and Tatastan, their possibilities for improvement in the future.

\section{Results and Discussion}

If we are to refer to regulatory control, then it may be pointed out that young families' housing provision is viewed as a state act of youth policy. That is told us by the analysis of such documents such as Decree of Supreme Council of the Russian Federation since 03.06.1993 N 5090-1 "Regarding main courses of state youth policy in Russian ", Bases of state youth policy of Russian Federation for timeframe up until year 2025. However, acts implementation to provide young families with housing is done exclusively in the framework of the housing policy of Russia (RF) and Tatarstan (TR). It is signified by the documents such us Decree since 25 the august year 2015 №889 «Regarding establishing federal targeting plan "Household" for years 2015-2020.», state plan «Quality housing and communal-utility services populace TR provision for years 2014-2021", approved by TR cabinet ministers decree since 30th April year 2014 N 289, etc.

Although young family, and housing policy documentation analysis has demonstrated sufficient discrepancies even in the "young family" meaning itself. In the framework of youth policy on federal and regional levels, there is no single truthful interpretation of this concept.

In the framework of housing policy, completely different demands are determined for a young family: age (up to 35), lack of sufficient housing area, financial capability to fund the main portion of buying/building a housing. Thus, such interpretation utterly and completely does not meet the previously described definitions.

Let us thread to the administrative aspect of young families' support. Previously made document analysis has shown that implementation of young families support is executed by agencies of housing policy (Ministry of constructions and HCS RF and Ministry of constructions architecture and HCS TR) exclusively without the involvement of state 
agencies responsible for youth policy - Federal agency of youth affairs, and Ministry TR of youth affairs. Thus, already on the level of regulatory and administrative acts, we can see difficulties and contradictions in young families' support organisation. Next, let us refer to the economic aspect of youth support when acquiring housing.

Currently, the main act to support young families in resolving the housing issue is subsidies provision to young families to buy/build housing. From a financial point of view, providing such support means providing subsidies from federal to local budgets; those, in their turn, spread funds between municipalities for direct-targeted families support. On the regional level amount of executed acts, as well as sources of their funding and amount of subsidies, are established by regional plans [13]. Let us take a closer look at acts to support young families and their housing quality improvement in TR funding.

The total amount of funding for the acts in TR for the 2017-2019 timeframe is represented as Table 1.

Table 1. Indicators of general funding amount measures providing young families with housing in Tatarstan, thous, rub

\begin{tabular}{llll}
\hline & Total funding & & $\%$ \\
\cline { 2 - 4 } & Plan & completed & 124,8219 \\
\hline 2017 & 134189,2 & 167497,6 & 150,6921 \\
\hline 2018 & 143703,7 & 216550,2 & 120,8921 \\
\hline 2019 & 136885,3 & 165483,6 & 1 \\
\hline
\end{tabular}

From chart 1 we see that the total budget of the plan fluctuates. If we are to complete a comparison pf planned and factual funding indicators, we may notice that achieved funding indicators are significantly higher primary ones. It might be reviewed as an indicator that the governors of the regions are eager to enlarge funding due to the demand and relevance of measures to support young families in TR.

Next, let us take to funding sources measures of young families' support analysis. In TR amount of funding measures to provide young families with housing is distributed in the following way depending on sources of funding. (see Table 2).

Table 2. Funding measures sources to provide young families with housing in TR, thous. rub. \%

\begin{tabular}{|c|c|c|c|c|}
\hline & & 2017 & 2018 & 2019 \\
\hline \multirow{3}{*}{$\begin{array}{l}\text { From } \\
\text { budget }\end{array}$} & plan & 5189,20 & 14703,70 & 7885,30 \\
\hline & completed & 5137,99 & 14685,98 & 7834,81 \\
\hline & $\%$ & $99,01 \%$ & $99,88 \%$ & $99 \%$ \\
\hline \multirow{3}{*}{$\begin{array}{l}\text { From } \\
\text { budget }\end{array}$} & plan & 50000,00 & 50000,00 & 50000,00 \\
\hline & completed & 48711,78 & 49165,00 & 49183,05 \\
\hline & $\%$ & $97,42 \%$ & $98,33 \%$ & $98,36 \%$ \\
\hline \multirow{3}{*}{$\begin{array}{l}\text { From } \\
\text { budgets }\end{array}$} & plan & 0,0 & 0,00 & 0,00 \\
\hline & completed & 0,0 & 0,00 & 0,00 \\
\hline & $\%$ & & & \\
\hline \multirow{3}{*}{$\begin{array}{l}\text { From } \\
\text { out-of-budget } \\
\text { funding }\end{array}$} & plan & 79000,0 & 79000,00 & 79000,00 \\
\hline & completed & 113647,80 & 152699,21 & 108465,70 \\
\hline & $\%$ & $143,86 \%$ & $193,29 \%$ & $137,29 \%$ \\
\hline
\end{tabular}

From chart 2 we can see that in TR only 3 out of 4 potential funding sources are used. Wherein, if objective indicators of budget expenses on supporting young families insignificant, but falls back behind from planned 
indications, then amount of invested out-of-budget funds (citizens' own funds) exceeds planned indications. This tells that young family - receives of the said supports are ready for more significant personal investments into housing than the plan originally envisaged it. This can also be reviewed as an indicator of population interest in such state support.

We will also assess the proportion of different sources of financing in solving the housing problem of young families (see Table 3).

Table 3. Portion distribution from different sources in total funding amount and measures of supporting young families in TR, \%

\begin{tabular}{llllll}
\hline $\begin{array}{l}\text { Funding } \\
\text { portion }\end{array}$ & $\begin{array}{l}\text { From budget } \\
\text { funding, including }\end{array}$ & $\begin{array}{l}\text { From federal } \\
\text { budget }\end{array}$ & $\begin{array}{l}\text { From regional } \\
\text { budget }\end{array}$ & $\begin{array}{l}\text { From local } \\
\text { budgets }\end{array}$ & $\begin{array}{l}\text { Out of } \\
\text { budget funds }\end{array}$ \\
\hline 2017 & 32,15 & 3,07 & 29,08 & 0,00 & 67,85 \\
\hline 2018 & 29,49 & 6,78 & 22,70 & 0,00 & 70,51 \\
\hline 2019 & 34,46 & 4,73 & 29,72 & 0,00 & 65,54 \\
\hline The average & 32,03 & 4,86 & 27,17 & 0,00 & 67,97 \\
\hline
\end{tabular}

Regarding the ratio of funds from budgets of different levels and extra-budgetary sources, it can be noted that the share of budgetary funds almost completely corresponds to the established rate of payment to young families: $30 \%$ or $35 \%$ depending on the number of family members. The average share of budget expenditures for making this payment should be from 30 to $35 \%$, which is observed in the TR. This suggests that the size of the subsidy to young families in the TR, calculated on the basis of the standard cost of 1 sq.m. Housing is really close to the market price, which is optimal. This allows, on the one hand, providing significant financial support to young families, and on the other hand, not to increase the burden on budgets of different levels.

To fully evaluate the effectiveness and efficiency of financing measures to provide housing for young families in the Republic of Tatarstan, we turn to the data on the number of families that received support (see Table 4)

Table 4. Data regarding the number of families who have received support in the framework for providing young families with household in TR, unit

\begin{tabular}{llll}
\hline & \multicolumn{2}{l}{ Quantity of families received support } \\
\cline { 2 - 4 } & Plan & Completed & $\%$ \\
\hline 2017 & 45 & 61 & 136,0 \\
\hline 2018 & 67 & 69 & 103 \\
\hline 2019 & 54 & 54 & 100 \\
\hline
\end{tabular}

Based on the data presented in table 4, it can be argued that the TR policy regarding young families can indeed be considered cost-effective. If the share of budget expenditures is optimal, budget expenditures do not exceed the planned values, the number of families that received support remains above the desired level. That is, in the TR, higher rates are achieved, with lower budget expenditures. First, this is provided by extra-budgetary investments of citizens themselves with the improvement of their own living conditions. However, if we evaluate the social effectiveness and usefulness of support measures for directly young families, here we can note some negative trends. You can observe a discrepancy in the trends of indicators. Thus, the amount of extra-budgetary funds invested is significantly larger than the planned indicator, and the number of families that received support differs insignificantly from the planned one. That is, with more substantial extra-budgetary expenses, we do not receive an equally significant increase in young families provided with housing. Such a decrease in social efficiency from support measures implemented in the TR may, in the future, raise the question of the relevance and feasibility of young families participating in this type of support. 


\section{Summary}

Thus, according to the results of the consideration of various aspects of the act to provide housing for young families, the following was established. So far, many issues regarding young families and their support in solving the housing problem remain unresolved. There is no single definition of a young family and the criteria for its determination, there is no clear attribution of the considered event to youth or housing policy, the issue of administering this event by youth or housing policy authorities remains unresolved. Moreover, these issues, first of all, should be resolved at the federal level.

Regarding the regional level, we can say that in Tatarstan, on the example of which the analysis of the financing of the considered support for young families was carried out, an optimal system for calculating the number of subsidies to young families was built. Which allows not increasing the burden on budgets, including regional, but at the same time stimulating young families to invest in the purchase (construction) of housing on their own. This allowed us to conclude that the cost of support is cost-effective. But at the same time, a conclusion was drawn about a lower level of social effects of the event: despite the fact that support, judging by the indicators, is relevant, nevertheless, the number of families receiving it increases slowly, while the household expenses of families to purchase housing grow much faster. That is, the average family expenses for the purchase of housing from year to year are becoming more and more.

\section{Conclusion}

Undoubtedly, nowadays, the accommodation issue is one of the most concerning issues of modern societies. In the survey, regulatory, administrative, and financial aspects have been investigated regarding the housing policies. Finally, some practical and feasible measures and approaches are proposed to at least alleviate this issue.

Based on the study outcomes, it is worth mentioning that aid for young families to address the accommodation issue is exceptionally urgent for the state now. However, it remains mostly unresolved. At the federal level, there is still no clear legal and organizational basis for promoting young families. In this regard, many questions about housing for young families are settled at the regional level independently. Since the organization of public administration in the Russian Federation regions varies significantly from each other, it can be assumed that the experience of supporting young families also varies greatly. Hence, housing efficiency for young families is defined depending on the work of state bodies in each region. As for the Republic of Tatarstan, it was found that an optimal system of financing measures to provide housing for young families was built here. Nonetheless, the number of families that received support remains relatively small. Given that, in Tatarstan, it is necessary to extend the measure of support for young families in the future.

\section{Acknowledgements}

The work is performed according to the Russian Government Program of Competitive Growth of Kazan Federal University.

\section{References}

Coulter, R., Bayrakdar, S., \& Berrington, A. (2020). Longitudinal life course perspectives on housing inequality in young adulthood. Geography Compass, 14(5), e12488

Darra, S., Ward, M. R., Jones, C., \& Jones, S. (2020). Young parents' experiences of a multi-agency young families project: Findings from a co-produced study. Children and Youth Services Review, 105146.

Decree of August 25, 2015 No. 889. (2020). On approval of the federal target program "Housing" for 2015-2020. Consultant Plus. Retrieved from http://www.consultant.ru/document/cons_doc_LAW_33773/

Fiori, F., Graham, E., \& Feng, Z. (2020). Inequalities in the transition to homeownership among young people in Scotland. Housing Studies, 35(3), 506-536.

Galster, G., \& Wessel, T. (2019). Reproduction of social inequality through housing: A three-generational study from Norway. Social Science Research, 78, 119-136.

Hikichi, H., Ni, M. Y., \& Leung, G. M. (2020). Parental cohabitation and mental well-being amongst young adults in the world's densest population with least affordable housing: Evidence from the FAMILY Cohort. Journal of Affective Disorders.

Kennelly, J., \& Watt, P. (2012). Seeing Olympic effects through the eyes of marginally housed youth: changing places and the gentrification of East London. Visual Studies, 27(2), 151-160.

Natalier, K., \& Johnson, G. (2012). Housing pathways of young people who have left out-of-home state care. 
Housing, Theory and Society, 29(1), 75-91.

Order of the Government of the Russian Federation of November 29, 2014 No. 2403-r. (2020). On approval of the Fundamentals of the state youth policy of the Russian Federation for the period until 2025. Electronic fund of legal and normative-technical documentation "Consortium Code". Retrieved from http://docs.cntd.ru/document/420237592

Palma, J., \& Scott, J. (2020). The implications of changing living arrangements for intergenerational relations in Chile. Contemporary Social Science, 15(3), 392-405.

Parker, S., \& Mayock, P. (2019). They're Always Complicated but that's the Meaning of Family in My Eyes: Homeless Youth Making Sense of "Family" and Family Relationships. Journal of Family Issues, 40(4), 540-570.

Resolution of the Cabinet of Ministers of the Republic of Tatarstan dated April 30, 2014 N 289. (2020). Electronic fund legal and regulatory -technical documentation "Consortium Code". Retrieved from http://docs.cntd.ru/document/553168439

Resolution of the Supreme Council of the Russian Federation of June 3, 1993 No. 5090-1. (2020). On the main directions of state youth policy in the Russian Federation". Electronic fund of legal and normative-technical documentation "Consortium Code". Retrieved from http://docs.cntd.ru/document/9004367

\section{Copyrights}

Copyright for this article is retained by the author(s), with first publication rights granted to the journal.

This is an open-access article distributed under the terms and conditions of the Creative Commons Attribution license (http://creativecommons.org/licenses/by/4.0/). 